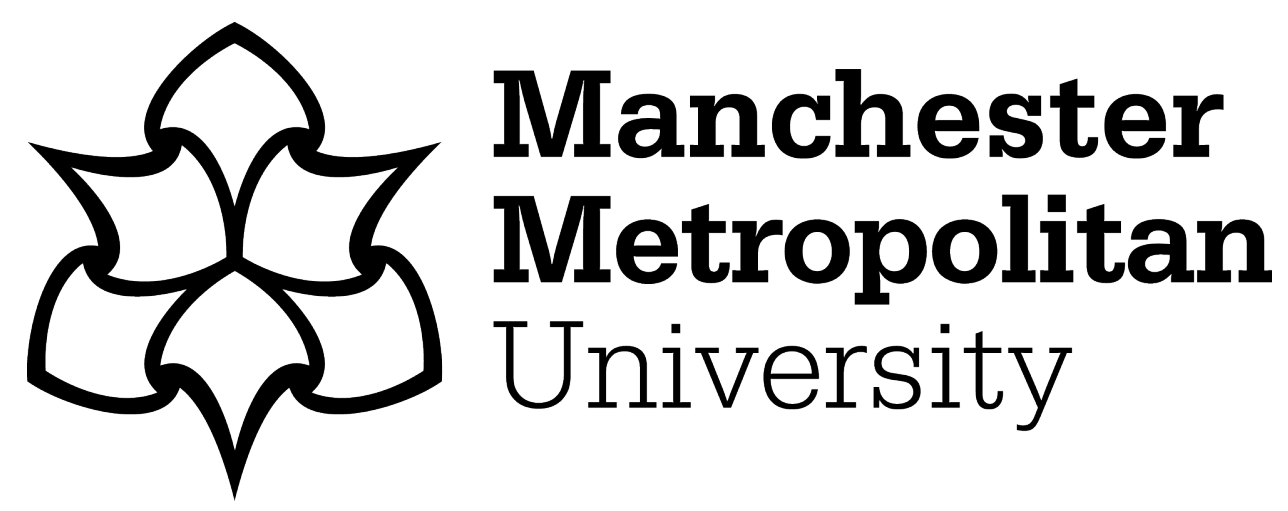

Colley, Helen (2003) Engagement mentoring for socially excluded youth: problematising an 'holistic' approach to creating employability through the transformation of habitus. British journal of guidance and counselling, 31 (1). pp. 77-99. ISSN 0306-9885

Downloaded from: https: //e-space.mmu.ac.uk/14184/

Version: Accepted Version

Publisher: Routledge

DOI: https://doi.org/10.1080/0306988031000086189

Please cite the published version 


\title{
Engagement mentoring for socially excluded youth: problematising an 'holistic' approach to creating employability through the transformation of habitus
}

\author{
Helen Colley
}

Published in 2003 in British Journal of Guidance and Counselling 31 (1) 77-100.

\begin{abstract}
This paper traces the emergence of engagement mentoring, which seeks to re-engage socially excluded youth with the formal labour market by altering their attitudes, values, and beliefs. Engagement mentoring has been promoted in European and British policy as an holistic response to social exclusion, for example in the new Connexions service. However, the original meaning of 'holism' has become contested, and policies and practices which claim to be holistic require clearer analysis. Drawing on Bourdieuian theory, and evidence from recent research, this paper interrogates the holistic claims of engagement mentoring from the perspective of its intended effects on mentees. It argues that the model treats personal disposition - habitus - as a raw material to be wrought into 'employable' dispositions, with little or no acknowledgement of institutional or structural fields of power. However, habitus is highly complex, with deep-rooted and collective aspects not easily transformed. A greater understanding of habitus might result in more genuinely holistic approaches to mentoring, and counter a perceptible policy drift towards totalitarian rather than holistic practice.
\end{abstract}

\section{Introduction ${ }^{1}$}

A new model of mentoring - engagement mentoring - has recently emerged as an intervention with socially excluded young people, epitomised by the new Connexions service, with its thousands of learning mentors and personal advisers. As such, it is closely connected with the professions of guidance and youth work, from which mentoring has now evolved as a discrete practice. Engagement mentoring is also a central plank of a number of other similar government initiatives, as well as inspiring many localised volunteer-based programmes. Such mentoring is rapidly achieving the status of a popular social movement in its own right (Freedman, 1999).

This paper briefly defines engagement mentoring, and traces its development, in particular the claims of both practitioners and policy-makers that it represents an holistic approach to supporting young people in difficult adolescent and career transitions. It goes on to interrogate these different claims through a genealogical analysis of the term 'holism', mapping shifts in its meaning as it has shuttled across borders and between different domains. It argues that there are clear criteria for distinguishing between genuinely holistic approaches, and those which claim holism, but are in fact merely 'totalitarian' in the way they seek to reform young people.

Supporting evidence is presented from case studies of mentor-mentee relationships in one English engagement mentoring scheme that formed a pilot for Connexions. These focus on the experiences of the young people, and the contrast between intended and actual outcomes of the mentoring process for them. (The important parallel impact upon mentors is not dealt with in this article, but has been addressed elsewhere, see Colley, 2001a, 2001b, 2001c). This data is considered in the light of Bourdieu's concepts of habitus and field, as a way of conceptualising the 
power dynamics of engagement mentoring. The case studies illustrate the usefulness of these concepts for developing a more genuinely holistic approach to mentoring socially excluded young people. The paper concludes by considering serious ethical implications for the policy and practice of engagement mentoring, and suggesting ways forward for the many professionals and volunteers who are becoming involved.

\section{The emergence of engagement mentoring}

Engagement mentoring is a term I have used to designate a particular form of mentoring for socially excluded youth that emerged in the US in the early 1990s, and in Britain in the latter half of that decade. Examples include a range of projects funded by the European Youthstart Initiative (Employment Support Unit (ESU), 2000), including the Institute of Career Guidance (ICG) national Mentoring Action Project (MAP) (Ford, 1999). There was also a series of local projects funded through the voluntary sector (e.g. Benioff, 1997; and see Skinner \& Fleming, 1999, for a review of over 40 similar schemes). However, since the election of the Labour government in 1997, engagement mentoring has been embraced by policy makers as a central feature of initiatives such as Excellence in Cities, the Learning Gateway, New Deal for Young People, and the new Connexions service. They hope that it can 'boost educational standards, ease social problems, and even reduce crime' (Prescott \& Black, 2000).

I have given a fuller account elsewhere of this model of mentoring and the socio-economic context for its development (Colley, 2001a). In brief, engagement mentoring has a number of defining characteristics. Firstly, its nature is planned and formalised within institutional settings and agendas. Such formal programmes contrast with the informal mentoring relationships that many vulnerable young people seek out for themselves, in which agendas are negotiated without the intrusion of external, third-party interests (Philip \& Hendry, 1996). Secondly, engagement mentoring is targeted specifically at socially excluded young people, and its aim is to re-engage those young people with the labour market and structured routes thereto. Legal and financial compulsion is sometimes a factor in engagement mentoring, as young people's welfare benefits may be stopped if they do not participate.

Thirdly, the role of mentors in this process is defined as that of transforming young people's attitudes, values, behaviours and beliefs - in short, their dispositions so that they acquire 'employability'. Employability is often defined as the requirement for young people to engage their personal commitment to the needs of employers and the economy (e.g. Department for Education and Employment (DfEE), 2000a, 2000b; Industry in Education, 1996; Glynn \& Nairne, 2000) There is, of course, nothing strikingly new in this concept of employability shaping various education and training frameworks in an instrumental way (cf. Bathmaker, 2001), but its influence upon the practice of mentoring has barely been questioned or investigated until now. Finally, the vehicle for such reform of disposition is that of a close human bond developed through a dyadic relationship between mentor and mentee that is often represented as quasi-parental (Ford, 1999).

While this brief description suggests some of the interests governments and employers might have in promoting this form of mentoring, it is important to recognise that it could not have achieved its current popularity without also capturing the mood of practitioners and the public in some way. An important aspect of this mood lies in existing professional commitments to holistic approaches in supporting adolescents in transition. 


\section{Holistic approaches to mentoring}

Holism has been fundamental to the ethos of guidance and counselling since the impact of Carl Rogers' client-centred work in the 1960s (e.g. Rogers, 1967) when career transitions became no longer regarded as a matter of mechanistic trait-andfactor matching. Given these ethical roots, it is not surprising that one of the most powerful contemporary expressions of practitioner interest in holistic approaches to Imentoring can be found in Geoff Ford's report (1999) on career guidance mentoring in the mid-1990s. The preface of the MAP report defines five key words that are used throughout, and one of those is the concept of 'holism':

The dictionary defines holism as 'the treatment of any subject as a totally integrated system'...Within guidance, where the predicament of the client cannot normally be considered separately from the individual's social context, it entails giving full consideration to social and personal issues... Holism is integral to all high quality career guidance because career choice can never be wholly dissociated from the other factors (values, circumstances, responsibilities etc.) which make up each person's life (Ford, 1999, p.11).

It goes to explain the difficulties of applying such an approach within the statutory framework for guidance services that pertained at that time:

However, resource and time constraints normally mean that in practice careers advisers have to discipline the adoption of holistic approaches [to those factors] which appear most directly related to career choice. For disengaged young people, the adoption of such disciplined approaches to guidance can mean that advisers are unable to touch the root causes of the individual's inability to progress (Ford, 1999, p.11).

It is particularly important to understand the context in which this emphasis on holistic practice arose. Ford describes the MAP as a project which 'could be seen to necessitate participant careers services sailing against the prevailing current of career guidance practice' at that time $(1999$, p.24). Careers services were restructured through their severance from local authorities in 1995. The guidance policies of the then Conservative government promoted blanket interviewing and action planning of clients. Such targets 'seemed inexorably to be leading towards career guidance becoming a service aimed predominantly at those within full-time education' (Ford, 1999, p.24). They both mitigated against the possibility of more resource-intensive work with young people outside the 'mainstream', and were also perceived by many practitioners to involve a level of prescription that undermined their professional autonomy and de-skilled them in the process. The additional time and space that the MAP was able to create by accessing European funding was also a time and space in which practitioners could regain a welcome degree of autonomy that was restricted within statutory provision, and where professional ethics could play a more unfettered role. In this respect, holistic practice in mentoring socially excluded young people represented a reaction against the technical rationalism of prevailing guidance policy (Hodkinson \& Sparkes, 1995; Hodkinson, Sparkes \& Hodkinson, 1996), and an avenue for subversive resistance to the imposition of that policy perspective.

Ford describes the advent of the MAP as a 'sea-change'. It represented sailing against the tide in 1995, but in 1997, with the election of the Labour government, that tide turned and led onto favour (if not fortune) for its focus on mentoring disadvantaged young people. Since then, many European and British policy responses to social exclusion among young people have claimed to advocate an 
holistic approach. Before examining these claims, and analysing the extent to which policy approaches may or may not have shifted towards a client-centred ethos, let us look more closely at the concept of holism itself. Foucault's work in particular (e.g. 1972,1991 ) has demonstrated the value of engaging in the archaeology of language, and of tracing the genealogy of ideas to understand their meanings more clearly. Strathern (1997, p.306) has similarly argued that it is necessary to examine the origins and subsequent 'borrowings and crossing of domains' of a concept in order to achieve clarity about its meaning, including covert meanings it may convey. Just such a genealogy of 'holism' may also be helpful here.

\section{A genealogy of 'holism'}

The Concise Oxford English Dictionary defines holism as a philosophical theory 'that certain wholes are greater than the sum of their parts', and as a medical approach that treats 'the whole person, rather than just the symptoms of a disease'. Phillips (1976) offers a useful historical review of its emergence and development. While the roots of holism may indeed be traced back to the field of philosophy, and to Hegel's revolution in introducing the dialectical method, the word itself did not enter the English language until the 1920s, in the scientific field of biology.

Just as the assertion of holistic practice in mentoring arose partly as a reaction to technicist guidance policies, so did the origins of holistic thought in biology also emerge from a reactive impetus to the dominant positivist paradigm of science at that time. Holism refuted key aspects of traditional scientific thought. These included mechanistic theories, which viewed the whole of a phenomenon as a conglomerate of articulated parts, rather than as a complex and dynamic set of interrelations; atomistic analysis, which enforced an artificial separation of elements for isolated consideration, and sacrificed a wider perspective for the sake of microscopic precision; and reductionist theory-building, which treated the characteristics of complex entities as a sum of the properties of its parts plus a set of covering laws. The holistic biologists also challenged the fundamental purposes that underpinned positivist scientific methodology. They objected to the nomothetic principle that science should concern itself with identifying laws and predicting outcomes of processes in order to control them, since this failed to address the unpredictable emergence of new characteristics in organic systems, and privileged explanations of cause and effect that were not feasible or appropriate for understanding new knowledge that had come to light.

Why did this radical challenge to established scientific method occur at this time? What spurred it? Revolutions in scientific thought almost always occur when the dominant paradigm finds itself in an impasse, unable to process or explain new developments or information that have come to light (Kuhn, 1970). Holistic biology developed first in the study of evolution and reproductive cellular biology, confronting the fact that mechanistic science had found itself increasingly unable to account for the knowledge of evolution that Darwin's discoveries had produced some decades earlier. The holistic challenge was not restricted to the physical sciences, however. Durkheim had already argued in social science that individuals had to be understood in their relationship to society as a whole, and that their actions had to be interpreted in relation to large-scale social phenomena. In psychology, Gestalt theory challenged behaviouristic models, arguing that they failed to do justice to the full complexity of human behaviour. The holistic revolution quickly spread across other intellectual domains.

It did not wait until 1995 to emerge in the fields of education or youth support and guidance. Dewey had already insisted on the importance of the relationship between the knower and the environment they know, and in the 1960s the holistic 
approach was central to the development of progressivist educational practice and the person-centred counselling theories of Carl Rogers. However, these developments were swiftly resisted, even vilified by powerful dominant groupings (Martin, 1997), as we are reminded by recent commentaries on the $25^{\text {th }}$ anniversary of James Callaghan's speech to launch the 'Great Debate' at Ruskin College in 1976. Corporate interests and policy makers alike asserted then, and have done so ever since, an instrumentalist notion of education and guidance which considers both as subservient to the needs of the economy. This instrumentalism is perhaps one of the most important points of contention for those who advocate an holistic approach:

Children do not exist to fuel economic growth...They exist in their own right as persons...Education conceived entirely in instrumental terms, whether for the homing of a fine tool in the economy, or for furthering personal ambition to 'get on', is out of balance (Reeves, 1997, cited in Martin, 1997, p.9).

The travels of holism do not end here, however, in a simple opposition to instrumental approaches to education or mentoring. We need to explore two more of its domain-crossings to understand the current status of the concept. One of the journeys made by holism in the 1980s found it being absorbed into a particular discourse of business management, epitomised by the writings of Deming on Total Quality Management (TQM), and of Senge on 'learning organisations'. These claim that continuous improvement can be achieved by targeting every aspect of an organisation, all its 'stakeholders', and every element of performance.

This managerialist discourse and its claim to holism has not been restricted to industry, but has quickly shuttled back into the field of education and guidance (Avis, Bloomer, Esland, Gleeson, \& Hodkinson, 1996). One example not so far engagement mentoring is the practice of recording achievement. This has also laid claim to holism since it first appeared in the early 1980s. Yet it has been argued that records of achievement, far from representing 'the whole person', serve to codify young people's responses to already-prescribed, atomistic categories of ideal-typical employee attributes. Recording of achievement:

...offer[s] pupil-focussed but not pupil-centred assessment...[It] has hijacked the notion of centredness in education... At the heart of ...profiling and reviewing lies an educational paradox: by constructing the student-centred, holistic and personalized profile, we de-individualize the learners by asking each one of them at the same time to conform to a stereotype, and to be themselves. (Stronach, 1989, p.169-170.)

Such approaches in fact represent everything that is antithetical to the original concept of holism. They appropriate the notion of holism in a rhetorical fashion, but apply it in a wholly inappropriate way by confusing totality (a sum of parts) with the whole (an organically inter-related entity). One important consequence is that individual attributes of the person become divorced from wider contexts including social structures. This confusion also needs clarifying in the policy and practice of engagement mentoring.

\section{Mentoring policy and holistic approaches}

It is striking to note the ways in which recent European and national policies for mentoring have claimed to promote holistic practice towards work with socially excluded young people. The European Commission (EC) documentation on the Youthstart Initiative, which funded the MAP and over 50 other UK projects 
incorporating mentoring, explained that it advanced a new model of support for young people, that of a 'comprehensive pathway':

Young people experiencing difficulties entering the labour market need a coherent and integrated package of support measures which addresses their individual needs and helps them tackle the personal and vocational barriers to employment which they encounter. The comprehensive pathway approach...tackles these barriers and meets their needs in a holistic and integrated way (EC, 1998, p.6).

Similar statements have accompanied national policy reformulation under New Labour. The Social Exclusion Unit report Bridging The Gap (1999, p.8-9) lays claim to an holistic approach of 'joined-up working' in addressing the multiple disadvantages which are faced by some young people, and which cross the boundaries of many welfare services. The Department for Education and Employment ${ }^{2}$ (DfEE) argued that a key principle of the Learning Gateway was that it must be 'learner driven and responsive to the needs of individuals' (DfEE, 1999a, p.3). An 'holistic approach to young people's needs' is highlighted as the primary consideration for assuring the quality of support for youth transitions (DfEE, 1999a, p.40). Another set of Learning Gateway guidelines admits the importance of the 'core conditions' of holistic, client-centred models of guidance, although at the same time it suggests that practitioners in the Learning Gateway should utilise more directive techniques with the 'hardest to help', and recommends that '...the non-directive method associated with Rogers becomes a guided approach' (DfEE, 1999b, p.5.5). Potentially holistic principles of multi-agency 'coherence' and 'integrated' provision to address multiple problems faced by young people are fundamental to the Connexions strategy, along with notion that young people themselves should be involved in aspects of the design, implementation and evaluation of the Connexions service. (DfEE, 2000c).

How can we judge whether the popularity among policy makers of holistic approaches to guidance and mentoring is real or rhetorical? The origins of holistic thought suggest two criteria for answering this question. The first concerns the purposes and outcomes to which a practice is dedicated. Are these nomothetic and prescriptive, or are they able to allow for emergent novelty and unpredictable consequences? The second concerns the distinction between two different meanings of the 'whole person' in question. Is the person treated as an organic, complex, dynamic whole in which all of the parts must be understood in relation to each other? Or does the approach lay claim to being 'holistic' simply by dint of seeking to affect the totality of its object, while still treating that totality as a sum of parts?

\section{The purpose of mentoring}

In relation to the first of these criteria, the policy context for engagement mentoring centres on the Labour governments' shibboleth that the solution to social exclusion is integration into the formal labour market. The widespread imposition of employment-related goals in mentoring for socially excluded young people have been criticised both from a perspective of social justice (e.g. Colley \& Hodkinson, 2001; Gulam \& Zulfiqar, 1998; Piper \& Piper, 1999, 2000; Watts, 2001), as well as on the grounds that they are simply inappropriate for some individuals (Colley, 2000a, 2000b; Ford, 1999; ICG, 1999, n.d.). Nonetheless, despite acknowledging the value of 'soft' outcomes (such as increased self-confidence), policy-makers continue to insist on 'hard' outcomes of progression into formal education, training and employment as the main requirement for funding. As the above review of policy documentation from new mentoring initiatives has shown, the achievement of such 
prescribed outcomes increasingly requires the prescription of practice. While there have been moves to involve young people in the development of the Connexions service, one notable area in which they are not permitted to help shape its design is that of its required outcomes and targets (DfEE, 2000c).

In fact, the entire rationale of the Connexions service and initiatives such as Excellence in Cities, expressed most clearly in Bridging The Gap, is about nomothetic prediction and prescriptive control - two key indicators of a positivist rather than an holistic approach. These policies are based on the view that risk of social exclusion can be predicted by the age of 13, that early and specific interventions (often focused on mentor support) can guarantee prevention, and that re-engagement with 'mainstream' career pathways will follow. This includes the notion that the power of a close, personalised relationship with a mentor or 'personal adviser' can and should effect very radical changes in young people's dispositions and belief systems. There is no room for emergent novelty or unpredictable outcomes in this approach, despite substantial evidence that young people's career decisions can be highly idiosyncratic and serendipitous (Hodkinson \& Sparkes, 1997), that crises in their transitions are sometimes precipitated by unpredictable events such as serious accidents, illnesses and bereavement (Ford, 1999), and that some of them are making increasingly unconventional lifestyle choices (Law, 2000).

\section{How engagement mentoring constructs the 'whole person'}

The second criterion for judging whether or not engagement mentoring is genuinely holistic relates to the way it constructs its object. Does it treat the "whole person' of the mentee as an organic entity, understanding its parts in relation to each other? Or does it simply target the totality of those parts, and (re)construct them in relation to externally determined objectives?

I have argued elsewhere (Colley, 2000c) that a major shift has occurred in contemporary accounts of career transitions through the dominance of a particular, triumphalist discourse of globalisation. This shift promotes three common themes: firstly, an acceptance of working conditions that serve the interests of employers in globally competitive markets, but represent intensified exploitation for the workforce through increased productivity, decreased job security, and wage competition; secondly, the view that guidance should help clients re-invent their own identities as marketable products, particularly in their willingness to demonstrate commitment to their employers' interests; and thirdly, the notion that a key role of practitioners is to overcome young people's resistant attitudes to these demands. Current UK policies relating to youth transitions,

so commonly expressed now in the reductionist terms of the requirements of international economic competitiveness, are almost exclusively concerned with the production of future workers with particular skills or dispositions...the work ethic and human capital theory generate between them a very utilitarian version of what it is to be a young person in contemporary society (Maguire, Ball \& Macrae, 2001, p.199, emphases added).

In addition to becoming tied to employment-related outcomes, mentoring for socially excluded young people, whether delivered through Connexions, other specific initiatives, or as an element of vocational training, has come to focus on young people's dispositions - the very heart of what it is to be a person.

EC policy for the Youthstart Initiative stated, in relation to its 'comprehensive pathway' approach, that: 
Each of the stages of the pathway is associated with bringing about a significant shift in the values and motivation of the young people, their skills and abilities and in their interaction with the wider environment. (EC, 1998, p.6, emphasis added).

The use of mentoring within Youthstart projects was recommended:

to reinforce the acceptance of values and attitudinal change amongst the young people (EC, 1998, p.12, emphasis added).

Which values and attitudes are to be instilled in young people, and in whose interests, are left open to question. A clue is offered, however, by this definition of part of the mentors' role in supporting young people:

[to] endorse the work ethic, and... challenge any negative perceptions the young person may have about entry to the labour market (ESU, 2000, p.7).

Similarly, Learning Gateway policy offers this view of the role of Personal Advisers:

In order to achieve all of these tasks, it is important for the Personal Adviser to recognise that many of the young people entering the Learning Gateway need support to change their attitudes and behaviours. Until they do so, these will continue to be barriers to their reintegration (DfEE, 1999a, p.9, emphasis added).

Bridging The Gap (SEU, 1999) offers the same analysis, that key barriers to young people's engagement with the labour market are represented by their own attitudes, values, beliefs and behaviour, and therefore the primary object of support systems for youth transitions has to be the alteration of those dispositions.

These discourses have impacted considerably upon the way in which young people's school-to-work transitions are understood and interpreted for young people themselves by agencies guiding them through those transitions: careers services, schools, colleges and training providers. One of the most important ways in which they have done so is through the notion of 'employability'. Discussions of the 'new world of work' often focus on the argument that it requires new types of skill to function in post-Fordist organisations. Prime importance is ascribed to skills that have variously been termed 'core skills', 'key skills' or 'transferable skills', which are often summarised through the concept of employability. It has been argued that these have acquired 'almost totemic status' (Green, 1997, p.88) and a ritual character within education and training (Ahier, 1996; Stronach, 1989). But what are they commonly held to be?

Numerous policy documents and research reports present a similar picture (e.g. DfEE, 2000a, 2000b; Glynn \& Nairne, 2000), but the report Towards Employability by the employers' organisation Industry in Education (1996) offers perhaps the starkest presentation. This report emphasises employers' demands for 'compromise and respect' in young workers (p.9), that staff need to 'sign on to the values and ethos of the business and sit into its organisational structure, culture and work ethics...to "go with" the requirements of the job' (p.10), and that young people need to consider and adapt 'their own values, attitudes, human interactions...' (p.10) in line with the interests of the employing organisation. It is not surprising, then, that the requirement for employability in young people has been criticised as having 'more to do with shaping subjectivity, deference and demeanour, that with skill development 
and citizenship' (Gleeson, 1996, p.97; see also Ainley, 1994; Avis, 1996; Hyland, 1996). It is for these reasons - the purpose of re-engaging young people with the formal labour market, by engaging their personal commitment to meet the demands of employers - that I have come to refer to mentoring in this context as 'engagement mentoring'.

There is, in one sense, little new about this. Employers' demands for employable young people has been described as 'the long moan of history', reaching back at least a century (Rikowski, 2001, p.30). More recently, in the 1970s, the Manpower Services Commission (MSC) conducted research which showed that:

Most employers in the survey regarded young people in a relatively unfavourable light and considered the quality of young applicants to be declining. Given the choice of recruiting a young person or alternative such as upgrading an existing employee, hiring from other employers in the area or hiring a female returnee, most employers indicated a preference for the alternative (Hasluck, 1999, p.31, referenced to Casson, 1979).

The MSC's remit, supported by large resources, was to promote behaviourist approaches in vocational education and training in order to reshape the young working class population as a 'new model workforce' (Killeen, personal comment). The success of that project remains open to question. However, it is important to note here that, despite some similarities in objectives, the behaviourist model of the 70s never posed such a direct mission of intervening in individual dispositions through the vehicle of human relationships, as engagement mentoring does today.

I agree with Maguire et al. (2001) that the current approach constructs the object of mentoring as the very personhood of the mentee in its entirety. If one could indeed change a person's values, attitudes, beliefs and behaviour, we might well question whether they would remain the same person. At the same time, by focusing on individual aspects of personal disposition, structural aspects which shape young people's trajectories, including inequalities and oppression deriving from class gender, race and age etc., are glossed over and dismissed. According to this analysis, dominant policies for mentoring and guidance do indeed target the entirety of the person, but not through an holistic approach as it was originally defined. They target aspects of the person and give them meaning in relation to external objectives determined by the interests of dominant others, not in relation to each other.

\section{New Beginnings - an engagement mentoring scheme}

In order to illustrate the problems of current approaches, I will draw on evidence from a recently completed research project (Colley, 2001a). The research approach I adopted was a critical interpretive one, focusing particularly on questions of class and gender, given my own disposition as a working class woman with a socialist feminist perspective. I conducted an 18-month case study of a Youthstart scheme I shall anonymise as New Beginnings. The scheme was run by a Training and Enterprise Council (TEC) $)^{3}$. It recruited 'disaffected' 16 and 17-year-olds, provided them with a programme of pre-vocational basic skills training and work experience placements, and aimed to progress them into work-based youth training or employment. In partnership with the local university, the scheme also offered the young people the option of being allocated a mentor for one hour a week. The mentors were undergraduate students recruited and trained by the university. When the Youthstart funding came to an end, the provision was continued as the local pilot for the Learning Gateway, and eventually formed part of the new Connexions service. 
The fieldwork was undertaken from December 1998 to July 2000, consisting primarily of repeated semi-structured interviews with individual mentors and mentees matched in nine established relationships, and with managers of the scheme.

The New Beginnings scheme clearly fitted the model of engagement mentoring. The senior manager responsible for the scheme at the TEC outlined her definition of the role she hoped New Beginnings mentors would play:

Mentoring was about befriending, and helping us, perhaps using a different way of talking to the young person, to help that young person to see what we were trying to get...trying to help them with. So the focus was very clearly about getting them into employment. That was very clear, that that's what the mentoring process was about.

The training course and the manual which accompanied it was dominated by the idea that the mentors' main goal was to help get the young people into employment. The handbook posed the overall aims of mentoring within the scheme in this instrumentalist way:

What is the purpose of education and training? ... Primarily education and training can lead to a particular role within the workforce.

Conversations in mentoring sessions were expected to focus on discussion of the personal development plan (PDP) drawn up for the young person each week. Two of the mentoring relationships are described here, to illustrate contrasting perspectives on the process of working on young people's dispositions.

\section{Adrian's story: a radical transformation of disposition}

Adrian had been schoolphobic, and had suffered depression and anxiety, agoraphobia and an eating disorder in his early teenage years. He lived with his mother, and their relationship was very difficult. He described his post- 16 choice as a stark one: between coming to New Beginnings and committing suicide. When I talked to him, he had just been sacked from the scheme after 13 weeks, but he was still very happy that he had chosen New Beginnings, mainly because of his relationship with his mentor, Patricia. Adrian spoke about his experience of mentoring with an evangelical fervour:

To be honest, I think anyone who's in my position, who has problems with meeting people, being around people even, I think a mentor is one of the greatest things you can have. I'd tell any young person to have a mentor... What Pat has done for me is, you know, it's just to turn me around and give me positive thoughts... If I wouldn't have had Pat, I think I'd still have the problems at home...Y You know, she's put my life in a whole different perspective.

He spoke very warmly of Patricia, and how she had helped him develop a better way of relating to his mother, and given him a self-confidence he had previously lacked.

Adrian's ambition when he took the enormous step of coming to New Beginnings was to work towards employment in the IT industry. He felt that 'computers are the way forward'. However, New Beginnings only offered a very limited range of training and work experience placements, concentrated in the lower end of the buoyant local labour market. He was placed in an office as a filing clerk, and was sacked after only a few weeks because of lateness and absence at his work 
placement. This caused major problems for the New Beginnings staff, who had to work extremely hard to get employers to offer placements, and did not want to lose them because of the young people's behaviour. Adrian had provided excuses such as a grandfather's funeral and a dental appointment on each occasion, but staff had waited in their cars outside the crematorium and the dental surgery to ascertain that he had not in fact been there. His actions were interpreted by the staff as showing that he had gained sufficiently in confidence, and therefore no longer needed the individual support provided through New Beginnings. Their feeling was that Adrian had been 'swinging the lead' and that 'he didn't really want to work'. He was not officially recorded as having been dismissed from the scheme. He was offered a place in a mainstream job club also based at the TEC, paying only $£ 20$ a week (less than half the New Beginnings training allowance), and his records therefore show him as an outcome of positive progression, with the implication that his problems were solved.

Adrian and his mentor Pat both gave a different view of these events. Pat, a former personnel manager and now a student teacher, was concerned that Adrian had unidentified learning difficulties that were causing him to miss work through fear of getting things wrong. She tried to advocate on his behalf with New Beginnings staff, to no avail. Adrian told me that he had become demoralised in a placement which did not at all match his modest career aspirations and interests. He felt he had not been given any proper training, but was unfairly condemned to all the 'crap jobs' nobody else wanted to do. He had felt depression creeping on again, and some days he simply could not face going in to work - hence his false excuses. It seems likely that both his and his mentor's accounts each reflected part of the wider process. However, the greatest blow for Adrian was that his dismissal from the scheme abruptly ended his relationship with his mentor in a kind of double punishment. The rules of the scheme meant that they were not allowed to keep in touch, and his feelings were understandably strong:

That was an unhappy time for me, you know, to just be cut off, just to be severed away from someone who you explain to and talk to and poured out your heart to, and I was very angry, to be honest.

One year on, Adrian was still unemployed after a number of brief false starts at the job club and on other schemes. Now over 18, he was anxious about his future, and saw 'time running out' as he passed the age limit of all the transitional support available. However, he still identified mentoring at New Beginnings as having provided major benefits, in that he now had the capacity to seek out new mentors for himself:

I think now I will attach to somebody, one person, you know, and I'll attach to them. You see that person, and you think, "Yes, I'll hang around with her or him".

Although he had not successfully entered the labour market, he talked a lot about the fact that he now felt like an adult, in contrast with the confusion he had felt about his 'in-between' status as a teenager before coming to New Beginnings. He had moved into his own council house, and begun to develop a group of friends of the same age. His relationship with mother was improving, and the worst of his mental health problems seemed to have receded.

Adrian's story shows how a positive relationship with an independent adult provoked a dramatic turning point in his life history and learning career. It broadened his ‘horizons for action' (Hodkinson et al., 1996) immeasurably, raising his 
aspirations, and giving him the desire to develop new knowledge and skills related to new technology. However, it was that very transformation of his attitudes, values and beliefs which took him beyond the pale of the restrictive vocational training opportunities reserved for socially excluded youth. His disposition was transformed, and he talked about how he felt he was a new and different person. Yet because his disposition was not transformed in the ways the scheme, mentoring policies, and employers' interest demanded, it resulted in his further exclusion from the education and training system, a punitive financial penalty, and the social penalty of losing his relationship with Patricia as well.

\section{Annette's story: the reinforcement of disposition}

The first time I met Annette in the summer of 1999, she was doing well on the training programme, and was doing her work placement at the New Beginnings office itself, as a clerical receptionist. She was working hard towards completing her NVQ Level 1 in Business Administration, as she was pregnant, and was due to leave the scheme to have her baby in the October. Annette had been placed in care by her father after her mother had died and he remarried. He had continued to work as a long-distance lorry-driver, and Annette had developed a close relationship with her older sister, and a very strong set of beliefs and values related to the importance of family life. Partly because of her father's negative attitudes, Annette wanted to gain a sense of success:

My dad always used to say that all my brothers and sisters would just be the same, we won't get nothing out of life, so I've got to achieve something.

Although this challenge had strengthened her temporary engagement with the goals of New Beginnings, it also created longer-term plans that conflicted with the aims of the scheme. Living independently with her boyfriend in a council house, Annette's main ambition was to become a full-time mother and establish her own family, as her sister had already done. Her pregnancy was planned:

Like, I know I'm only young, but I know what I want, and that's what I did want, a baby. It'll be brilliant because me and my boyfriend, we're really close anyway, we're dead close, so that's what we both really wanted, to settle down now.

Perhaps because of her own experiences of losing her mother and then being placed into care, Annette said that she would not consider looking for a job again at least until her child was old enough to start school.

Annette's mentor Jane was a mature Social Sciences student with a background in counselling. Jane recounted her attempt to follow the mentoring guidelines and structure her mentoring sessions around Annette's PDP:

Jane: I tried to do the things, the training that she needed, and the educational thing, and work placements, and talk about all of those, you know, the sort of text book of, you know, how it's supposed to be...go along that line of the PDP plan they have.

Annette, however, had her own thoughts about the purpose of mentoring:

Annette: We talked about everything, really, but like, mentors are mainly for work, but it wasn't really work that I did talk about. 
Jane began to worry that 'talking about everything' other than work was not what she had been taught on the mentor training course:

Jane: I'd worked with Annette for a few weeks, then I went back to read the training manual to see if I was doing it right. We'd got into talking about her pregnancy, her background, what had happened with her mum, her dad, social workers. I had to think: am I on the right lines here? And the manual tells you about this plan they have, their timetable, and it says you should work with that with the mentee every week. So I asked her for it, and she was shocked! I asked her to bring it in the next week so we could look at it together. But she never has. The manual says you are supposed to. She brought her hospital planner in instead, and she brings that every week.

She never asked for the New Beginnings planner again, and later identified this as a critical incident in their relationship:

Jane: I think that was the moment when Annette really began to trust me.

Annette, for her part, was clear about the benefits she had sought and obtained from her mentor:

Annette: She put my mind at rest when I was having problems with the baby. Like, 'cause she had a little girl as well. She just said, like, 'Don't worry, it's like all people have different pregnancies, and you're stuck with one of the bad ones, everything will come out fine'.

The planner which got brought to the mentoring meetings had proved to be a graphic symbol of victory for one of two competing agendas.

Nine months later, I met and interviewed Annette again. She was very proud of her young baby, and of her immaculately clean and tidy house, and she drew upon support from professional health workers as well as becoming incorporated into a lively social network of young mothers in her community. Because of the holistic, client-centred principles to which Jane had become committed through her study and practice of Rogerian counselling, she answered the dilemma of her mentor role by choosing to respond to the way Annette defined her own needs, rather than the way the scheme defined them. Unlike Adrian's story, the mentor in Annette's story helped to reinforce rather than transform her mentee's disposition, including her resistance to the imposition of employment-related goals.

However, despite Annette's success as a parent, and her moral conviction that 'a child needs its mother when it's young', she would probably register as a failure and as a continuing problem within the framework outlined in Bridging The Gap (SEU, 1999), where teenage pregnancy and single motherhood are construed as feckless deviance leading to benefit dependency. Moreover, under further Labour proposals to deal with the 'problem' of teenage pregnancy, published the week before my first interview with Annette (and to her indignation), she would have lost her right to her council house home, and been forced to enter hostel accommodation with welfare-to-work education and training provision.

In the light of these illustrative case studies, I wish to offer a theoretical framework which may allow us to make sense of this focus on personal disposition as the object of mentoring and guidance in current policy. I will do so by drawing on Bourdieu's concepts of habitus and field (Bourdieu \& Wacquant, 1992). 


\section{Practice as the interface of 'habitus' and 'field'}

It has been argued that Bourdieu's sociology represents the most adequate way of theorising the dialectical interplay of structure and agency particularly in relation to young people's school-to-work transitions (Ball, Maguire and Macrae, 2000; Hodkinson et al., 1996; Hodkinson \& Sparkes, 1997; Okano, 1993). Most recently, Philip and Hendry (2000) and Smith (2001) have drawn on Bourdieu's work in their research on mentoring. Bourdieu's inter-related concepts of field and habitus constitute a distinct theorisation of the articulation between structure and agency. Let us briefly review the meaning of these terms, before turning to explore their potential application to the research data.

It would be incorrect to see field as a representation of structure, and habitus as that of individual agency. This might lead to a neat, but misleading interpretation of the data. The field of engagement mentoring, the specific sites represented by New Beginnings, the Learning Gateway or the Connexions service, and other related fields (such as the economy, the political field, class structures, social gender roles) could be seen as narrowly constraining the individual actions of mentors, mentees or scheme staff. On the other hand, habitus counterposed to structure as individual agency in this way could offer an explanation of how each participant chose to respond within those overall constraints. However, this would represent a gross oversimplification of these concepts, and a distortion of the power dynamics involved.

For Bourdieu, field and habitus both express the dialectical relationship between structure and agency (Wacquant, 1992). As Hodkinson et al. (1996) note, Bourdieu's most frequent metaphor for field is that of a game. It thus comprises context in two ways. It is constituted by the terrain or playing-field, and by the rules that regulate play. However, the game is also constructed by those participating in it. They lend the game legitimacy by the very fact of taking part and playing according to its rules. On the other hand, they influence the game by the specific strategies and tactical choices they employ to achieve their own interests or goals.

This does not imply complete freedom, however, nor equality within the field of play. Players in the game occupy different positions within the field, that represent objective relations of domination or subordination (Bourdieu \& Wacquant, 1992: 97). In short, 'the field is a critical mediation between the practices of those who partake of it and the surrounding social and economic conditions' (Bourdieu \& Wacquant, 1992: 105).

Habitus entails a similar dialectic, since it is both

.... a structuring structure, which organises practices and the perception of practices, but also a structured structure: the principle of division into logical classes which organizes the perception of the social world is itself the product of internalisation of the division into social classes (Bourdieu, 1986, p.170, emphases added).

In less abstract terms, habitus can be understood as the combination in each person of previous biography, their sense of identity/identities, lifestyle, personality, class and cultural background, and the beliefs, attitudes and values that I have hitherto referred to as 'disposition'. Habitus, however, is used to express the fact that such dispositions are not purely subjective and unique to each individual in certain respects, but also, even in those personal respects, embody an important collective aspect:

To speak of habitus is to assert that the individual, and even the personal, the subjective, is social, collective. Habitus is a socialized subjectivity (Bourdieu \& Wacquant, 1992, p.126, emphases added). 
At the same time, Bourdieu rejects a deterministic interpretation of the concept:

Habitus is not the fate that some people read into it. Being the product of history, it is an open system of dispositions that is constantly subjected to experiences, and therefore constantly affected by them in a way that either reinforces or modifies its structures. It is durable but not eternal! (Bourdieu \& Wacquant, 1992, p.133, original emphasis).

Nevertheless, there is a 'relative' degree of closure in habitus, given the weight of prior experiences such as class, race and gender conditioning. Choices and agency are possible, although bounded. When exercised by individuals, they can bring about transformations of habitus. Habitus and field, then, are mediating factors that both enable and constrain the exercise of individual agency as well as wider structures of power.

Bourdieu argues that any analysis of a phenomenon must begin with an analysis of the field (Bourdieu \& Wacquant, 1992). Such an analysis has already been offered in the earlier part of this paper, in defining current mentoring policies in relation to the wider economic, social and political context in which these policies have been developed. Analysis must then move on to consider the habitus of the participants in the field, the individual and collective aspects of their dispositions, and their trajectory within the field in relation to the other players.

\section{Habitus as 'raw material'}

The case studies reveal the differential location and power of the young people, their mentors, and scheme staff within the New Beginnings site, as well as the imperatives imposed on staff through national and European policies and related funding régimes. Any reader familiar with Bourdieu's theories may already have noted how I have utilised the notion of disposition (or habitus) in the case studies, to suggest that habitus offers an explanation of individual choice and agency within the site and field. In the stories of Adrian and Annette, aspects of these young people's biographies, and those of their mentors, played an important part in shaping their mentoring relationship and their responses to the scheme. However, thinking about habitus as an explanation of individuals' choice of action in this way did not seem to tell the whole story.

In this paper, I have argued that, since engagement mentoring seeks to transform the dispositions of young people to become 'employable', the goal of these approaches is to produce/reproduce habitus in a particular way that is determined by the needs of dominant groupings, rather than by the individual needs or desires of participants in mentoring. Habitus thus becomes treated as a raw material which has to be worked on by mentors. It becomes reified as the object of practice. Mentoring becomes constructed as a set of labour processes which seek to re-form habitus as a saleable commodity within the labour market. Our own selves become dehumanised as human capital. The reproduction of labour in this way, through mentoring, or other aspects of guidance, education and training, has been described as an oppressive system that "seeks to enlist "hearts and minds"' (Bates, 1994, p. 29). In engagement mentoring, the greatest contradiction may be that this brutal commodification of the self is cloaked in the guise of human relationships based on warmth and compassion.

\section{Understanding habitus - a foundation for genuinely holistic practice}

I would argue, however, the complexity of habitus indicates the futility of trying to reify it in this way. As the case studies illustrate, the task of altering habitus 
is simply unfeasible in many cases, and certainly not to a set timescale - old habit(u)s die hard. Where, as in Adrian's case, change is effected, it is not possible to control the outcomes in the ways that policy-makers expect. Nevertheless, a more accurate understanding of habitus could offer a great deal to policy and practice in engagement mentoring.

Following Hodkinson et al. (1996), habitus is a useful theoretical concept for practice in relation to young people's transitions, because it helps account for individual agency, including the pragmatically rational aspects of career and lifestyle decisions. All too often, young people are seen as the passive recipients of mentoring, and any failure to comply with its directed agenda is interpreted as deviancy. Understanding habitus also encourages us to consider the dispositions and predispositions that influence young people's 'horizons for action'. It helps us to recognise the unpredictability of the 'turning points' that can occur in young people's lives, for better or for worse, and the directions in which their horizons for action may consequently shift. It can help mentors and personal advisers be alert to the emergent and novel perspectives that young people may rapidly develop as their life experiences move on.

In addition, understanding the collective and enduring nature of some predispositions takes the focus of practice away from a deviant-or-deficit model of the individual mentee. If mentors can acknowledge the social and economic factors which influence young people's situations and perspectives, they can also offer important help to their mentees to become aware of their collective social location in this way. Such a perspective avoids the danger of self-blame when the labour market is not so easy or attractive to enter, through no fault of the mentee.

These possibilities all reflect the original and genuine characteristics of an holistic approach. They pose crucial ethical questions for the emerging professions of personal adviser and learning mentor, as well as for established guidance and youth work professionals being transferred into new mentoring roles. Law (2000) argues that those involved in mentoring and other forms of guidance and support for young people cannot be immune from the pressure of agency targets, policy, or powerful corporate and political interests. He uses the notion of 'system orientation' to explain how practitioners in Connexions might comply with or resist such pressures to differing degrees. He emphasises the ethical importance of being fully aware of those pressures at the same time as maintaining a stance of openness towards helping the client/mentee on their own terms - especially when the mentee may have made a rational decision to reject official definitions of 'social inclusion'.

This requires mentors to develop a broader and more independent sense of their own role and possibilities within it, that may differ from official prescriptions, as Jane and Patricia did in the case studies. It also requires them to cope with, and find support for, the dilemmas and tensions this will inevitably create. As Law points out, this can be a risky and marginalising business for the mentor as well as the mentee. Unless a serious and thorough debate is pursued to clarify the nature of holistic practice, the very real danger is that engagement mentoring will not empower young people in finding their way through fragmented transitions, but act as a form of social control with totalitarian, rather than holistic, undertones.

\section{Note:}

1. An earlier version of this paper, entitled 'Old habit(u)s die hard', was given at the Institute of Education, London, at a seminar for the National Institute of Careers Education and Counselling (NICEC) in October 2001. 
2. The Department for Education and Employment was re-organised as the Department for Employment and Skills (DfES) in 2001, after the Labour government's re-election for a second term.

3. TECs were local government-sponsored agencies in England and Wales. They had a dual remit of co-ordinating the provision of youth training (and a much smaller amount of adult training), and of providing support for local businesses. They were abolished in 2001, and their training remit was handed to the newly formed Learning and Skills Councils (LSCs).

\section{Acknowledgement}

My thanks are due to the participants in the NICEC seminar for their helpful comments on an earlier version of this paper. I am also grateful to Kim Diment at the University of the West of England for her comments on my treatment of holism. 


\section{References}

AHIER, J. (1996), Explaining economic decline and teaching children about industry: some unintended continuities? In J.AHIER, B.COSIN \& M.HALES (Eds)

Diversity and Change: Education, Policy and Selection. London: Routledge.

AINLEY, P. (1994). Degrees of Difference. London: Lawrence and Wishart.

AvIS, J. (1996). The enemy within: quality and managerialism in education. In J. Avis, M.Bloomer, G.Esland, D.GleEson, \& P.HodKInson, Knowledge and Nationhood: Education, Politics and Work. London: Cassell.

Avis, J., Bloomer, M., Esland, G., GleEson, D., \& Hodkinson, P. (1996). Knowledge and Nationhood: Education, Politics and Work. London: Cassell.

Ball, S.J., Maguire, M. \& Macrae, S. (2000). Choices, Pathways and Transitions Post-16: New Youth, New Economies in the Global City. London:

RoutledgeFalmer.

BATES, I. (1994). A job which is 'right for me'? Social class, gender and individualization. In I.BATES \& G.RISEBOROUGH (Eds), Youth and Inequality. Buckingham: Open University Press.

BATHMAKER, A.-M. (2001). "It's the perfect education": lifelong learning and the experience of foundation-level GNVQ students. Journal of Vocational Education \& Training, 53(1), 81-100.

BENIOFF, S. (1997). A Second Chance: Developing mentoring and education projects for young people. London: Commission for Racial Equality /Crime Concern.

Bourdieu, P. (1986). Distinction: A Social Critique of the Judgement of Taste. London: Routledge.

Bourdieu, P. \& WACQuANT, L.J.D. (1992). An Invitation to Reflexive Sociology. Cambridge: Polity Press.

CAsson, M. (1979). Youth Unemployment. London: Macmillan.

Colley, H. (2000a). Mentoring disaffected young people: employment goals and power dynamics in mentoring dyads. Paper given at National Careers Research Network Conference. Centre for Guidance Studies, University of Derby, 18 January.

Colley, H. (2000b). Mind the Gap: Policy Goals and young people's resistance in a mentoring scheme. Paper given at British Educational Research Association Annual Conference. Cardiff University, 7 September.

COLley, H. (2000c). Deconstructing "realism" in career planning: how globalisation impacts on vocational guidance. In K.ROBERTS (Ed.), Careers Guidance Constructing the Future 2000. Richmond: Trotman/Institute of Careers Guidance.

Colley, H. (2001a). Unravelling Myths of Mentor: Power Dynamics of Mentoring Relationships with 'Disaffected' Young People. Unpublished PhD thesis, the Manchester Metropolitan University.

Colley, H. (2001b) Righting re-writings of the myth of Mentor: a critical perspective on career guidance mentoring, British Journal of Guidance and Counselling 29 (2) 177-197.

Colley, H. (2001c). Love's labour lost? Emotional labour in engagement mentoring with disaffected young people. Paper given at British Educational Research Association Annual Conference. Leeds University, 13 September.

Colley, H. \& Hodkinson, P. (2001). Problems with 'Bridging The Gap': the reversal of structure and agency in addressing social exclusion. Critical Social Policy, 21(3), 337-361. 
DEPARTMENT FOR EDUCATION \& EMPLOYMENT (DFEE) (1999a). A Guide to Relevant Practice in The Learning Gateway for 16 \& 17 Year Olds. Nottingham: DfEE Publications.

DfEE (1999b). Guidance on Assessment in the Learning Gateway for 16 \& 17 Year Olds. Nottingham: DfEE Publications.

DFEE (2000a). Labour Market and Skill Trends 2000. Nottingham: Skills and Enterprise Network/DfEE Publications (Ref: SEN 373).

DFEE (2000b). Skills for All: Proposals for a National Skills Agenda - Final Report of the National Skills Task Force. Sudbury: DfEE Publications (Ref: SK728).

DfEE (2000c). The Connexions Strategy Document. Nottingham: DfEE Publications (Ref: CX2).

EMPlOYMENT SUPPORT UNIT (ESU) (2000). Mentoring Young People: Lessons from Youthstart. Birmingham: ESU.

European Commission (EC) (1998). Unlocking Young People's Potential. Luxembourg: Office for Official Publications of the European Communities.

FORD, G. (1999). Youthstart Mentoring Action Project: Project Evaluation and Report Part II. Stourbridge: Institute of Careers Guidance.

Foucault, M. (1972). The Archaeology of Knowledge and the Discourse on Language. New York: Pantheon Books.

Foucault, M. (1991). Discipline and Punish: The Birth of the Prison. London: Penguin.

Freedman, M. (1999). The Kindness of Strangers: Adult Mentors, Urban Youth and the New Voluntarism. Cambridge: Cambridge University Press.

GLEESON, D. (1996). Post-compulsory education in a post-industrial and post-modern age. In J. Avis, M.BloOMER, G.Esland, D.GleESON, \& P.HodKInSON, Knowledge and Nationhood: Education, Politics and Work. London: Cassell.

Glynn, C. And NAIRne, B. (2000). Young People's Attitudes to Work, Careers and Learning. Horsham: Roffey Park.

GREEN, A. (1997). Core skills, general education and unification in post-16 education. In A.Hodgson \& K.SPOuRs (Eds,), Dearing and Beyond: 14-19 Qualifications, Frameworks and Systems. London: Kogan Page.

GulaM, W. \& ZulFIQAR, M. (1998). Mentoring - Dr.Plum's elixir and the alchemist's stone. Mentoring and Tutoring, 5(3), 46-56.

Hasluck, C. (1999). Employers, Young People and the Unemployed: A Review of Research. Sheffield: Employment Service (Ref: ESR12).

HODKINSON, P. \& SPARKES, A.C. (1995). Markets and vouchers: the inadequacy of individualist policies for vocational education and training in England and Wales. Journal of Education Policy, 10(2), 189-207.

HODKINSON, P. \& SPARKES, A.C. (1997). Careership: a sociological theory of career decision making. British Journal of Sociology of Education, 18(1), 29-44.

Hodkinson, P., SPARKES, A.C., \& HodKInsOn, H. (1996). Triumphs and Tears: Young People, Markets and the Transition from School to Work. London: David Fulton.

Hyland, T. (1996). National Vocational Qualifications, Skills Training and Employers' Needs: beyond Beaumont and Dearing. Journal of Vocational Education and Training, 48(4), 349-365.

INDUSTRY IN EDUCATION (1996). Towards Employability: Addressing the Gap Between Young People's Qualities and Employers' Recruitment Needs. London: Industry in Education.

Institute of CAREERS GuIDANCE (ICG) (1999). Focusing the Work of the Careers Service. Stourbridge: ICG (Positional Statement No. 38). 
ICG (n.d.). Learning to Succeed - A New Framework for Post-16 Learning: The Institute's Response to the White Paper, incorporating comment on the recommendations contained in the Report of the Social Exclusion Unit 'Bridging the Gap: New Opportunities for 16-18 Year Olds not in Education, Employment or Training'. Stourbridge: ICG.

Kunn, T.S. (1970). The Structure of Scientific Revolutions. Chicago: University of Chicago Press.

LAw, B. (2000). Fasten your seatbelts: orienteering the ethical landscape. Careers Guidance Today, 8(4), 33-36.

Maguire, M., BALl, S.J. \& MACRAe, S. (2001). Post-adolescence, dependence and the refusal of adulthood. Discourse, 22 (2), 197-211.

MARTIN, C. (1997). The Holistic Educators: Education for the $21^{\text {st }}$ Century. Nottingham: Educational Heretics Press.

OKAnO, K. (1993). School to Work Transition in Japan. Clevedon: Multi-Lingual Matters.

PHILIP, K. \& HENDRY, L.B. (1996). Young people and mentoring - towards a typology? Journal of Adolescence, 19(3), 189-201.

PHILIP, K. \& HENDRY, L. (2000). Making sense of mentoring or mentoring making sense? Reflections on the mentoring process by adult mentors with young people. Journal of Community and Applied Social Psychology, 10, 211-233.

PHILliPS, D.C. (1976). Holistic Thought in Social Science. London: Macmillan Press.

PIPER, H. \& PIPER, J. (1999). 'Disaffected' young people: problems for mentoring. Mentoring and Tutoring, 7(2), 121-130.

PIPER, H. \& PIPER, J. (2000). Disaffected young people as the problem. Mentoring as the solution. Education and work as the goal. Journal of Education and Work, 13(1), 77-94.

PRESCOTT, M. \& BlaCK, E. (2000). Government $£ 500 \mathrm{~m}$ pledge for teenage mentors. Sunday Times, 30 January, p.1.

REEVES, M. (1997). Letter to The Independent, 18 February.

RIKOWSKI, G. (2001). Education for industry: a complex technicism. Journal of Education and Work, 14(1), 29-49.

Rogers, C.R (1967). On Becoming a Person: A Therapist's View of Psychotherapy. London: Constable.

Skinner, A. \& Fleming, J. (1999). Mentoring Socially Excluded Young People: Lessons from Practice. Manchester: National Mentoring Network.

SMITH, K. (2001). The development of subject knowledge in secondary initial teacher education: a case study of physical education student teachers and their subject mentors. Mentoring and Tutoring, 9(1), 63-76.

SOCIAL EXCLUSION UNIT (SEU) (1999). Bridging the Gap: New Opportunities for 1618 Year Olds. London: The Stationery Office.

StronaCH, I. (1989). A critique of the 'new assessment': from currency to carnival? In H.SimONS \& J.ElliotT (Eds), Rethinking Appraisal and Assessment. Buckingham: Open University Press.

STRATHERN, M. (1997). 'Improving ratings': audit in the British University system. European Review, 5(3), 305-321.

WacQuant, L.J.D. (1992). Preface. In P.Bourdieu \& L.J.D.WACQUANT, An Invitation to Reflexive Sociology. Cambridge: Polity Press.

WAtTs, A.G. (2001). Career guidance and social exclusion: a cautionary tale. British Journal of Guidance and Counselling, 29(2), 157-176. 